\title{
Public Open Space in Sumatera Utara, Indonesia: Potency, problem and design idea
}

\author{
Achmad Delianur Nasution, Wahyuni Zahrah \\ Faculty of Architecture \\ Universitas Sumatera Utara, Indonesia \\ aan.nasution@gmail.com
}

\begin{abstract}
The study means to formulate some design ideas for public open space (POS) in small towns of developing country, while the vehicles grow fast and create a car-dependent community. The analysis is begun with identification potency and the problems of the POS that based on the field survey of 21 POS in Sumatera Utara province. There are 1346 respondents involved. They are the visitors that are doing their activities in the POS. Then, the study looks out some factors of POS to offer some design solutions. The study points out an implementing strategy to make the ideas applicable.

Keywords: design guidelines;public open space; Indonesia;

eISSN 2398-4279 @ 2018 . The Authors. Published for AMER ABRA cE-Bs by e-International Publishing House, Ltd., UK. This is an open access article under the CC BY-NC-ND license (http://creativecommons.org/licenses/bync-nd/4.0/). Peer-review under responsibility of AMER (Association of Malaysian Environment-Behaviour Researchers), ABRA (Association of Behavioural Researchers on Asians) and $c E-B s$ (Centre for EnvironmentBehaviour Studies), Faculty of Architecture, Planning \& Surveying, Universiti Teknologi MARA, Malaysia.
\end{abstract}

DOI: https://doi.org/10.21834/ajqol.v3i13.170 


\subsection{Introduction}

One of the crucial problems in many towns and cities in Indonesia, particularly in Sumatera Utara Province, is the car-oriented planning and development. The plan denies the space for human. Meanwhile, the number of vehicles become higher and claim many spaces for circulation and parking (Zahrah et al., 2016). There is no place in the city for people to enjoy together the urban area by walking, but public open space (POS). POS becomes the room where citizens maintain and improve their quality of life by doing an interaction with the urban environment and the other people (Chiesura, 2004).

In the issue of the social gap and gated community (Aulia and Ismail, 2013), and the degradation of urban environment due to the pollution and traffic jam (Zahrah and Nasution, 2015), the presence of POS becomes essential among the other urban elements. The fact shows that no matter good or bad the design quality of POS is, the community keeps visiting it, make it an active and vibrant atmosphere in the town (Nasution and Zahrah, 2015). Since the Indonesia government applied autonomy regulation in 1999, there is an opportunity to enhance urban environment (Bunnel et al., 2013), including public open space. According to Kallus (2001) and Lang (1994), the POS get success while responding well the community preference. One of the ways to get the information of people needs is by asking their perception (Kallus, 2001). The authors have studied about how the community used and perceived the public open space in 21 towns in Sumatera Utara Province, Indonesia that involved 1346 respondents. The respondents were the visitors that doing their activities in the POS and agreed to participate in the survey. Based on the survey, the design idea is formulated.

\section{Potencies and problems of POS in Sumatera Utara}

\subsection{Potencies}

The potencies of the POS in town of Sumatera Utara province are as follows:-

\section{a. The active space for all people}

From the aspects of social background, age group and activities, POS in Sumatera Utara are the successful POS as mention by Gehl (2002). POS works well to be a free recreational facility for all ages groups. This is a different condition compares to capital city Medan, where people tends to come to many privatized public spaces, such as malls, theme parks, cafes and restaurants (Nasution and Zahrah, 2012). Most of visitors state that the primary motive they come to POS is to take sport-exercise and socialization (Table 1). With a minimum sports services, the activities occur intensively. (Table 2)

Table 1: The visitors' motivation coming to POS

\begin{tabular}{lcc} 
& Motiv & $\%$ \\
\hline Relaxation & 20,2 \\
Sport/exercise & 38,7
\end{tabular}


Playing

Picnicking

Gathering with family and or relatives Being alone
11,5

4,0

24,6

3,4
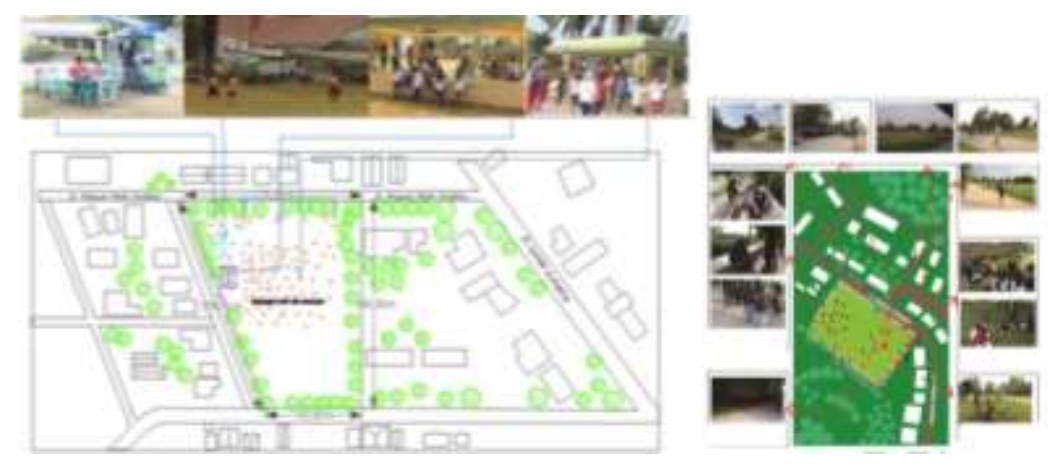

Figure 1: two examples of active POS in Sumatra Utara: Labuhan Utara (left) and Dairi (right) (Source: Field survey, 2015)

\section{b. The important communal space}

Most of POS in Sumatera Utara are squares, in the Indonesian language known as 'Lapangan Merdeka' (Independence Field). The official national ceremony, such as Independence Day, always takes place in this POS. The other periodical service is a place for Eid Prayer twice in a year, especially in towns of the Moslem majority. Besides, the square becomes a place for a general meeting of mass organization or political party, trading and cultural exhibition and festivals, as well as music and other cultural shows.

\section{c. The place for socializing}

The majority of people visits POS in a group. This fact points out that the POS works well to be a melting pot for socialization. The utilization duration of POS in these small towns is more intensive than Medan's POS (Nasution and Zahrah, 2014). Most of the citizens believe that POS can give positive contribution to their quality of life (Table 4)

Table 2: The intensity of POS utilization

\begin{tabular}{|c|c|c|c|c|c|c|}
\hline Variable & $\begin{array}{c}\text { Very } \\
\text { disagree }\end{array}$ & Disagree & $\begin{array}{l}\text { Less } \\
\text { agree }\end{array}$ & Agree & $\begin{array}{l}\text { Very } \\
\text { agree }\end{array}$ & $\begin{array}{c}\text { Average } \\
\text { score }\end{array}$ \\
\hline $\begin{array}{l}\text { Spend more than } 2 \text { hours in } \\
\text { POS } \\
\text { Come to POS more than } 3\end{array}$ & 5,3 & 5,7 & 12,1 & 55,6 & 21,2 & 3,82 \\
\hline times a week & 2,8 & 5,0 & 9,8 & 57,0 & 25,3 & 3,97 \\
\hline
\end{tabular}

Table 3: The intensity of POS utilization

\begin{tabular}{|c|c|c|c|c|c|c|}
\hline Variable & $\begin{array}{c}\text { Very } \\
\text { disgree }\end{array}$ & Disagree & $\begin{array}{l}\text { Less } \\
\text { agree }\end{array}$ & Agree & $\begin{array}{c}\text { Very } \\
\text { agree }\end{array}$ & $\begin{array}{c}\text { Average } \\
\text { score }\end{array}$ \\
\hline
\end{tabular}




\begin{tabular}{lcccccc}
\hline $\begin{array}{l}\text { Doing physical } \\
\text { activities }\end{array}$ & 1,9 & 3,9 & 7,6 & 58,0 & 28,6 & 4,08 \\
$\begin{array}{l}\text { Sitting and talking } \\
\text { with familiy/relatives }\end{array}$ & 1,0 & 2,7 & 8,3 & 62,7 & 25,3 & 4,09 \\
$\begin{array}{l}\text { Picnicking } \\
\begin{array}{l}\text { Say hello/greetings to } \\
\text { the other visitors }\end{array}\end{array}$ & 3,5 & 11,6 & 20,9 & 48,4 & 15,7 & 3,61 \\
$\begin{array}{l}\text { Grouping than being } \\
\text { alone }\end{array}$ & 5,6 & 2,9 & 7,9 & 61,7 & 21,8 & 3,91 \\
Being alone & 2,7 & 8,0 & 8,5 & 56,7 & 24,2 & 3,92 \\
\hline
\end{tabular}

d. The easy access

POS in small towns of Sumatera Utara province has the easy access from the community settlements due to a short distance and light traffic. POS in Sumatera Utara is perceived as quite good by the community (Table 3 ).

Table 4: Community perception about the benefits of POS to QOL

\begin{tabular}{lcccccc}
\hline \multicolumn{1}{c}{ Variable } & $\begin{array}{c}\text { Very } \\
\text { disagree }\end{array}$ & Disagree & $\begin{array}{c}\text { Less } \\
\text { agree }\end{array}$ & Agree & $\begin{array}{c}\text { Very } \\
\text { agree }\end{array}$ & $\begin{array}{c}\text { Average } \\
\text { score }\end{array}$ \\
\hline $\begin{array}{l}\text { The activity in POS } \\
\text { makes healthy }\end{array}$ & 2,9 & 2,9 & 6,0 & 59,6 & 28,6 & 4,08 \\
$\begin{array}{l}\text { Being in POS makes soul } \\
\text { more calm and relax } \\
\text { Visiting POS makes }\end{array}$ & 2,4 & 2,3 & 6,7 & 58,1 & 30,5 & 4,12 \\
$\begin{array}{l}\text { social cohesion better } \\
\begin{array}{l}\text { Being in POS makes a } \\
\text { happy feeling }\end{array}\end{array}$ & 2,7 & 2,7 & 6,6 & 59,9 & 28,1 & 4,08 \\
$\begin{array}{l}\text { POS makes urban } \\
\text { environment better }\end{array}$ & 0,9 & 2,2 & 7,9 & 60,7 & 28,3 & 4,13 \\
\hline
\end{tabular}

\subsection{Problems}

The promblems found in POS of Sumatera Utara are as follows:-

a. The car-dependent community and the absence of pedestrian linkage

POS in Sumatera Utara does not have a good pedestrian linkage as mentioned in some common indicators of a good public space (see Project for Public Space, 2000; Gehl 2002; CABE and DETR, 2001). The study demonstrates that more than $50 \%$ of visitors come to POS by motorcycle or private car, though the distance between POS and their home is less than one kilometer.

b. The street vendor

In many POS this nonpermanent merchant makes the space more active and vibrant. The problem is the space-ordering system, the design, and the regulation of the merchants is denied in many POS. The perception of the users about street vendor shows a low score (Table 5). 
c. The management

The cleanliness of POS is mostly terrible, neither the maintenance of facilities. The conditions is a consequence of the absence of an appropriate management organization.

Table 5: The people satisfaction level with POS facility

\begin{tabular}{lcccccc}
\hline \multicolumn{1}{c}{ Variable } & $\begin{array}{c}\text { Very } \\
\text { unsatisfied }\end{array}$ & Unsatisfied & Neutral & Satisfied & $\begin{array}{c}\text { Very } \\
\text { satisfied }\end{array}$ & $\begin{array}{c}\text { Average } \\
\text { score }\end{array}$ \\
\hline Widht & 2,7 & 7,4 & 24,0 & 46,5 & 19,4 & 3,73 \\
Parking lot & 3,8 & 21,8 & 24,5 & 39,1 & 10,8 & 3,31 \\
Pedestrian path & 3,3 & 15,2 & 27,5 & 38,3 & 15,7 & 3,48 \\
Toilet & 20,4 & 32,6 & 20,0 & 20,4 & 6,6 & 2,60 \\
Playing Area & 3,9 & 14,7 & 26,3 & 36,8 & 18,2 & 3,51 \\
Sport/exercising & & & & & & \\
Area & 2,8 & 10,5 & 23,8 & 44,1 & 18,7 & 3,65 \\
Sitting Area & 1,4 & 11,5 & 25,3 & 42,6 & 19,2 & 3,67 \\
Garden Area & 2,3 & 19,0 & 28,3 & 36,3 & 14,0 & 3,41 \\
Picnicking Area & 5,7 & 24,5 & 29,4 & 29,7 & 10,7 & 3,15 \\
Prayer Area & 8,6 & 26,7 & 26,3 & 25,9 & 12,5 & 3,07 \\
Dining Area & 5,3 & 16,4 & 30,1 & 34,7 & 13,5 & 3,35 \\
Street Vendor & 6,8 & 18,4 & 32,3 & 28,7 & 13,7 & 3,24 \\
\hline
\end{tabular}

\section{Design Idea}

\subsection{Basic Concepts}

The approach in determining the design guidelines is based on users' natures, so it is hoped that the plan can fit their needs. The community in Sumatera Utara that visit POS is mostly the low-income people, vehicle-dependence, like to engage in public activity, the Moslem majority, need a recreational facility for family, and does not have walking tradition. So the basic concept for the design is making POS as an educative-entertaining melting pot. It is necessary to propose a place where people can gather, express their culture as well as experiencing a responsive built environment.

\subsection{Location}

POS in this guideline is the square type. The study gives the fact that the plaza always located in the center of the town, near some key buildings, such as town hall, Grand Mosque, Post office, etc. The location is the best place due to its easy accessibility.

\subsection{Function and Activity}

The primary function POS that can meet community needs relates to:-

a. Daily public events, either active or passive. The passive activities include sitting, eating/dining, picnicking, and talking. The active ones include physical activity, such as playing, running, walking, exercising, and many kinds of sports. 
b. Periodical public events. These activities are done at a particular time, such as the collective prayer, art and culture festivals and exhibition, general meeting of the mass organization, trading expo, and bazaar.

c. Economic activity. POS is one of the possible places where the economic event occurs. It can be day-to-day operations or annual bazaar or trading expo.

d. Education and art function. The POS can be a media that educate and give information about history, culture, tradition and the mutual interaction between man and environment (Figure 2).

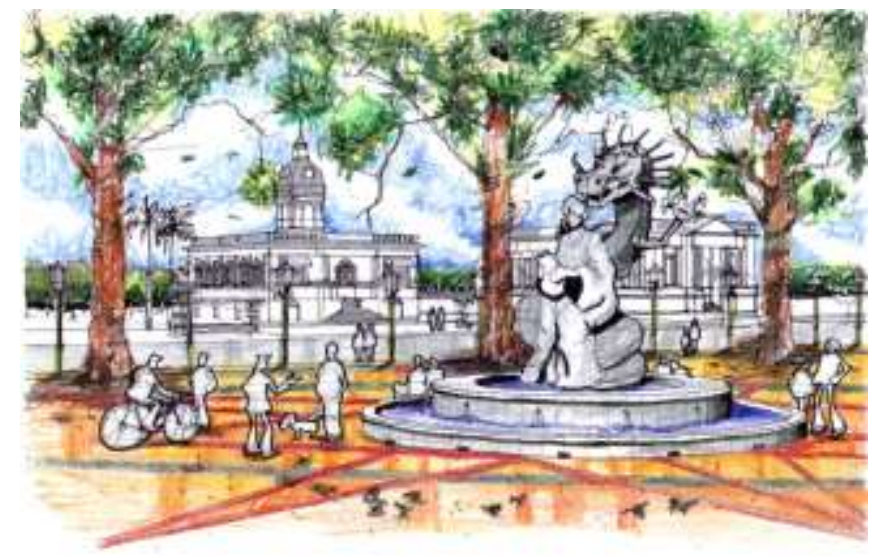

Fig. 2. Image impression of sculpture as art and historical educating media in POS

\subsection{Accesibility}

The existing POS is mostly accessed by private vehicle and hampers a healthy physical activity. It is necessary to make integration with the macro plan of the city. The implementation of this policy is by assigning the pedestrianization policy. Creating a linkage between housing location and activity centers is important. It is equal with improving the quality of pedestrian path so can attract more people to walk.

\subsection{Facility and design criteria}

The service seeks to support all the activities, either the daily and annual activities. The service design implements the standard public open space design with some modifications to fit local people needs, anticipation to vandalism behavior, and considering the easy and cheap maintenance. There some facilities has to be improved as mention below:-

\section{a. Gate}

The gate can be placed on all side of the square to make an easy access. It is necessary to put some interesting theme in the design, such as history or local culture.

b. Parking area

This area is design to be greenery, with trees and non-waterproof pavement. The zoneshould be easy-controlled, and has an adequate lighting in the night. 
c. Public transport shelter.

It is highly recommended to put a bus, trishaw and taxi shelter that connected with the pedestrian path. The facility should be set back to avoid street congestion.

d. Grass field

The area should be wide enough to accommodate the public official ceremony and or exhibition, sport-games, collective prayer and cultural show.

e. Pendopo (multi-purpose stage)

The pendopo is an open air building typology that used in the national ceremony for the invited audience. In daily used this building can be functioned as a place to art training, gathering, and discussion. The design of the pendopo can express local culture and should consider tropical climate and maintenance.

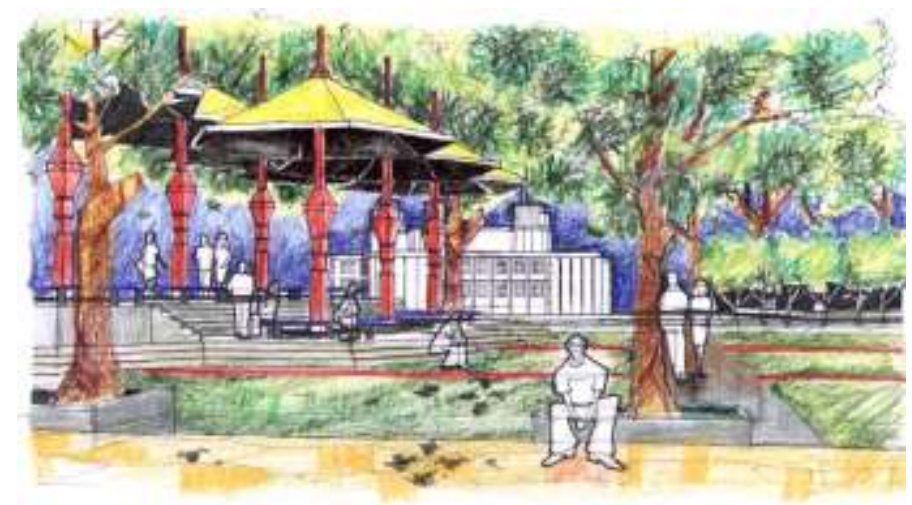

Fig. 3. Image impression of multi-purpose stage

\section{f. Playing/sports field}

Playing/sports field should be multi-purpose for some kinds of favourite sports games, such as basketball, volleyball, and badminton. It is recommended to consider national standard so it can be used in local sports competition.

g. Fitness Area

The fitness area can be located parallel with the pedestrian path /jogging track or clustered in a spot near children playground.

h. Sitting area

The sitting area design should have variation, so can accommodate all needs, both group, and single sitting. The material used should consider the weather and maintenance. The area should be protected from sun and rain. The protection can be a canopy, tree, or pergolavegetation. This area should be controllable visually from all direction to prevent crime and vandalism. The area should be located in a place that enables someone to watch something 
like an attraction, such as watching kids playing, the landscape objects, or sports activity.

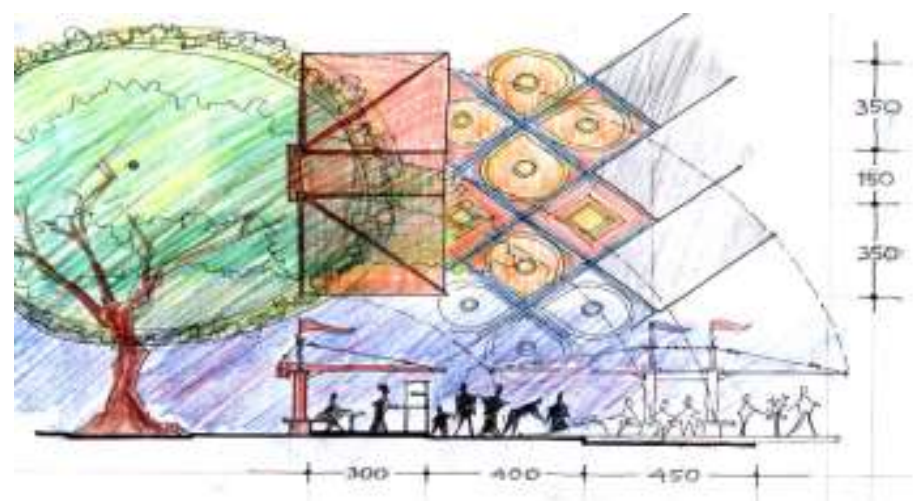

Fig. 4. The sketch of plan and section of sitting area that has a shady tree or canopy to ensure comfort

\section{i. Kids playground}

The playground can stimulate kid's motoric ability. This area should be ergonomics, safe, and controllable.

j. Jogging track

This track should long enough to enable people enjoying pedestrian activities. It is necessary to plan an individual track for biking to avoid conflict with pedestrians. The pedestrian path should be designed to be comfort, continue, and safe.

k. Public Toilet

The design should consider maintenance. The water source can implement rain harvesting because Sumatera Utara is a region with abundant rainy days.

I. Mushola/prayer facility

The facility can be conceived as an open-air building for saving energy and prevent other activities except praying. A moveable screen can be installed to protect it from rain.

m. Water outlet

In order to make ablution easy before prayer, it is necessary to provide water outlet. It does not take a particular place, but a lot of water outlet and drainage channel.

$\mathrm{n}$. Dining area and street vendor.

The street vendor can be placed in a cluster, in a paved area with adjustable canopy. This area should be equipped with adequate utility, such as fresh water, drainage and trash can. The utilization of this space should be supported by regulation, particularly in modifying design, extended area, and cleanliness. 


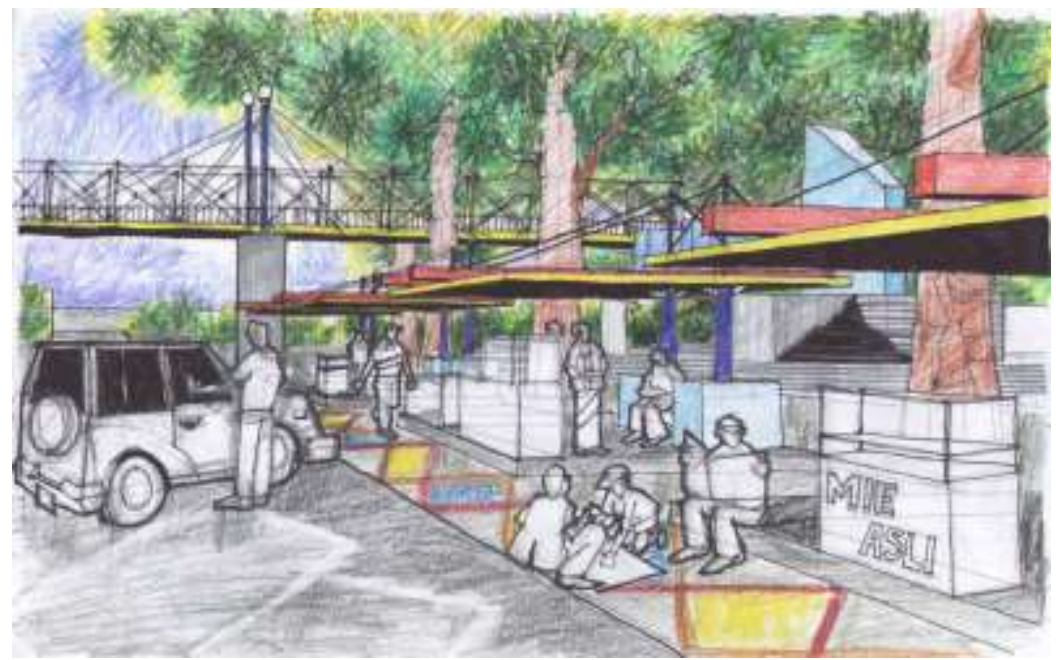

o. Trash can

Fig. 4 Image impression of street vendors spot

It is necessary to design this equipment strong enough to prevent vandalism. It should be distributed in every activity zone.

p. Lighting

The adequate lighting, particularly in the night, is critical to enable people doing their activities until night without worries about crime and immoral act. Since the conventional electricity is a crisis in Sumatera Utara, it is recommended to install lighting with renewable energy, such as solar panel/ photovoltaic.

q. Art and education objects

Art and learning objects can be integrated into the design of landscape and its features, such as sculpture, historical/legend figures, information board/signage that explain vegetation identity or city history, or pavement pattern that illustrated some knowledge and interesting information.

\subsection{Management}

Some problems of management aspects relate to cleanliness, safety, and maintenance. It is necessary to place some officers to enable safety and maintenance control.

\section{Implementing strategy}

Most of the Indonesian citizens, particularly in Sumatera Utara, do not have an experience about a tidy, orderly and good governance urban space. Evers (2007) said that many cities in Indonesia run 'urbanization without urbanism.' The transition from rural-agrarian to be urban-industrial community still express people with the rural tradition that live in a dense and complex infrastructure environment. The implementation problem is based on two 
fundamental aspects: the awareness of individuals and the capacity of government. The first point needs public education. The intensive campaign about how should people use and keep public open space has to be done either verbally and visually. The second aspect, the government capacity should be reflected by assigning the guidelines to be a government regulation. However, after 'marketing policy' to the people, the government should uphold the law enforcement to ensure all stakeholders apply the guidelines.

\section{Acknowledgement}

We gratefully acknowledge Kementrian Ristek Dikti Republik Indonesia for finance support for this research through Hibah Bersaing Research Grant 2016. We also thank all surveyors and respondents, which without their valuable contribution and collaboration this study could not be accomplished

\section{References}

Aulia, Dwira, and Ismail, Abdul Majid. (2013). Residential Satisfaction of Middle Income Population: Medan city. Procedia - Social and Behavioral Sciences 105 ( 2013 ) 674 - 683

Bunnell, T, Miller,MA, Phelps, NA, Taylor, J (2013). Urban development in a decentralized Indonesia: two success stories? Pacific Affairs 86 (4), 857-876

CABE and DETR (2001). The Value of Urban Design, London: Thomas Telford

Chiesura, Anna (2004) The Role of Urban Parks for The Sustainable City, Landscape and Urban Planning, 68 (2004) 129-138

Evers, Hans-Dieter (2007). The End of Urban Involution and Cultural Construction of Urbanism in Indonesia. Internationale Asienforum no. 1-2, pp 51-65

Gehl, Jan; Gemzoe, Lars (1996) Pubic Space - Public Life. The Danish Architectural Press and Royal Danish Academy of Fine Arts School of Architecture Publishers. Copenhagen

Gehl, Jan. (2002) Public Space and Public Life City of Adelaide: 2002. City of Adelaide, Adelaide.

Lang, J. (1994) Urban Design : The American Experience, Wiley: New York

Kallus, Rachel (2001). From Abstract to Concrete: Subjective Reading of Urban Space, Journal of Urban Design, Vol. 6, No. 2, 129-150

Nasution, Achmad Delianur, Zahrah, Wahyuni (2015). Public Life of Small Towns Public Open Spaces in North Sumatra Province. Proceedings 6th Asia-Pacific International Conference on Environment-Behaviour Studies,Barcelona School of Architecture (ETSAB), Barcelona, Spain,31 Aug.- 05 Sep. 2015 pp 375-383

Nasution, Achmad Delianur, Zahrah, Wahyuni (2012). Public open space privatization and quality of life, case study Merdeka Square Medan. Procedia - Social and Behavioral Sciences 36 (2012) 466 - 475

Nasution, Achmad Delianur, Zahrah, Wahyuni (2012). Neighborhood open space and quality of life in low-income 
Nasution, A.D., \& Zahrah, W. / Asian Journal of Quality of Life (AjQoL), 3(13) Sep/ Oct 2018 (p.138-149)

settlement: Rahmadsyah Square case study, Medan, Indonesia. Proceedings HABITechno International Seminar Innovation Housing and Settlement Technology. Bandung : ITB

Nasution, Achmad Delianur, Zahrah, Wahyuni (2014). Community perception on public open space and quality of life in Medan, Indonesia. Procedia - Social and Behavioral Sciences 153 (2014 ) 585 - 594.

Zahrah, W., Aulia, DN., Marpaung, B.O.Y., (2016). Koridor Ruang Kota Layak Huni: Budaya "Merampas" Ruang Publik?. Prosiding Temu IImiah IPLBI 2016, Halaman E 089-096

Zahrah, Wahyuni, Nasution, Achmad Delianur (2015). Urban design guidelines for shop houses: a climate modification approach. Procedia - Social and Behavioral Sciences 179 ( 2015) 308 - 31 